ORIGINAL ARTICLE

\title{
Species-rich but defaunated: the case of medium and large-bodied mammals in a sustainable use protected area in the Amazon
}

\author{
Dian Carlos Pinheiro ROSA ${ }^{1,3}$, Carlos Rodrigo BROCARDO ${ }^{1,3,4 *}$, Clarissa ROSA ${ }^{2}$, Arlison Bezerra \\ CASTRO $^{2,3}$, Darren NORRIS ${ }^{2,5,6}$, Rodrigo FADINI ${ }^{1,3}$ \\ 'Universidade Federal do Oeste do Pará - UFOPA, Programa de Pós-Graduação em Biodiversidade, Santarém, Pará, Brazil \\ 2 Instituto Nacional de Pesquisas da Amazônia INPA, Manaus, Amazonas, Brazil \\ ${ }^{3}$ Universidade Federal do Oeste do Pará - UFOPA, Laboratório de Ecologia e Conservação, Santarém, Pará, Brazil \\ ${ }^{4}$ Instituto Neotropical: Pesquisa e Conservação, Curitiba, Paraná, Brazil \\ ¿Universidade Federal do Amapá, Postgraduate Programme in Tropical Biodiversity, Macapá, Amapá, Brazil \\ ${ }^{6}$ Universidade Federal do Amapá, School of Environmental Sciences, Macapá, Amapá, Brazil \\ *Corresponding author: carlosbrocardo@hotmail.com; (D) https://orcid.org/0000-0003-3142-5688
}

\section{ABSTRACT}

Neotropical medium and large-bodied mammals are key elements in forest ecosystems, and protected areas are essential for their conservation. In Brazil, sustainable use protected areas (SU-PAs) allow both the conservation of biodiversity and the sustainable use of natural resources, especially in the Amazon region. However, SU-PAs usually suffer both internal and external pressures, and may be subject to variable degrees of defaunation. We sampled mammals using camera traps in two areas with different forest management and human occupation history in the Tapajós National Forest (TNF), in the western Amazon. Overall, we recorded a rich assemblage of medium and large-sized mammals, though both areas differed in species composition. The area with older and more intense human occupation and forest exploitation had more independent records of generalist species, while large species such as Tapirus terrestris and Panthera onca were recorded exclusively in the area with lower human occupation and no forest management. A comparison of our results with similar studies in other Amazonian sites suggests a reduction in the population size of large-bodied mammals, such as Tapirus terrestris and Tayassu pecari, likely in response to increased human activities. Local differences in human occupation within and between protected areas are common in the Amazon, demanding area-specific actions from public authorities to minimize impacts on wildlife caused by human activities. Specifically in TNF, we recommend long-term monitoring of the responses of mammals to human activities, to better subsidize conservation and management actions.

KEYWORDS: camera trapping, poaching, tropical forest, wildlife management

\section{Rica em espécies, mas defaunada: o caso de mamíferos de médio e grande porte de uma área protegida de uso sustentável na Amazônia}

\section{RESUMO}

Mamíferos neotropicais de médio e grande porte são elementos chave em ecossistemas florestais, e unidades de conservação são essenciais para sua conservação. No Brasil, as unidades de conservação de uso sustentável (UC-US) permitem tanto a conservação da biodiversidade quanto a exploração sustentável dos recursos naturais, especialmente na Amazônia. Porém, as UC-US geralmente são afetadas por pressóes internas e externas, e podem apresentar diferentes graus de defaunação. Amostramos mamíferos de médio e grande porte usando armadilhas fotográficas em duas áreas com distintos históricos de manejo e ocupaçáo humana na Floresta Nacional do Tapajós (FNT), na Amazônia ocidental. Em geral, registramos uma rica assembleia de espécies de mamíferos de médio e grande porte, mas as duas áreas diferiram na composição de espécies. A área com ocupação humana mais intensa e antiga e exploração florestal apresentou mais registros independentes de espécies generalistas, enquanto espécies maiores, como Tapirus terrestris e Panthera onca, foram registradas exclusivamente na área com menor ocupação humana e sem manejo florestal. A comparação de nossos resultados com estudos similares em outros locais na Amazônia sugere uma redução no tamanho populacional de mamíferos de grande porte, como Tapirus terrestris e Tayassu pecari, provavelmente em resposta ao aumento das atividades humanas. Diferenças locais na ocupação humana dentro de e entre unidades de conservação são comuns na Amazônia, demandando açóes específicas do poder público para minimizar impactos de atividades humanas sobre a fauna silvestre. Especificamente na FNT, recomendamos o monitoramento de longa duração das respostas de mamíferos às atividades humanas, para melhor embasar açóes de conservação e manejo.

PALAVRAS-CHAVE: armadilha fotográfica, caça furtiva, floresta tropical, manejo da vida silvestre 


\section{INTRODUCTION}

Medium and large-bodied mammals such as armadillos, agoutis, deer, tapirs, and peccaries, are important to maintain the structure of neotropical forests (Stoner et al. 2007; Oliveira et al. 2018; Villar et al. 2020a), but they are threatened by human activities, such as habitat transformation and poaching (Schipper et al. 2008). Many regions suffer from defaunation, a worldwide process of local or global animal species extinctions and population declines (Dirzo et al. 2014). Even preserved areas have experienced severe defaunation, especially of larger species, in response to overhunting (Redford 1992; Peres and Palacios 2007; Antunes et al. 2016; Galetti et al. 2017; Benítez-López et al. 2019). Indeed the term "empty forest" was coined by Redford (1992) based on studies of hunting to defaunation inside supposedly pristine Amazon forests. Global data indicate that mammal populations have had an average reduction of $83 \%$ in areas subject to hunting compared to non-hunted areas (Benítez-López et al. 2017). Defaunation compromises, directly or through cascade effects, the functionality of ecosystems, promoting changes in food webs, prey populations, nutrient cycles, plant regeneration and possibly reducing the carbon stocks in tropical forests (Brocardo et al. 2013; Bello et al. 2015; Sobral et al. 2017; Cooke et al. 2019; Villar et al. 2020a,b).

The creation of protected areas (PAs) is among the most successful strategies for protecting species, ecological interactions, and entire ecosystems, mainly because they keep natural habitats with size and conservation quality superior to those of unprotected natural areas in the same region (Bruner 2001). In Brazil, PAs are divided into two categories: strictly protected areas (S-PAs) and sustainable use protected areas (SU-PAs). The former are subjected to more restrictive use regulations, allowing scientific research and, in some cases, tourism, but no direct use of natural resources, while the latter allow the sustainable use of natural resources regulated by specific management plans, especially by local communities (Brasil 2000). In the Brazilian Amazon, more than half (64\%) of PAs are SU-PAs, which are important for the preservation of the social and cultural traditions of local communities and their different ways of interacting with the environment (ICMBio 2019). However, it is unclear to which extent the differences in human occupation within SU-PAs affect biodiversity, which demands effective conservation measures (Chape et al. 2005; Geldmann et al. 2019).

Bush meat consumption is widespread among rural and urban populations in the region, and hunting frequency is associated with the distance to forests (Torres et al. 2018). Also, forest degradation may alter mammal assemblages (Iwamura et al. 2014; Roopsind et al. 2017). Therefore, we hypothesized that mammal species presence and biomass vary within SU-PAs as a function of human occupation and impact, with a higher degree of defaunation in areas under longer and/or more intensive human use. We tested whether two areas with different histories of human use inside the same SU-PA in the western Amazon differ in their assemblages of medium and large-bodied terrestrial mammals. One area is close to riverine villages and urban centers, and has suffered degradation through fire and logging, while the other is distant from human occupation, inserted in a less fragmented and degraded matrix. We compared our results with other studies on mammal defaunation in the Amazon basin, and discuss the importance of our study site for the conservation of medium to large-bodied species of mammals in the regional context.

\section{MATERIAL AND METHODS}

\section{Study area}

Our study was carried out in the Tapajós National Forest (TNF) $\left(2^{\circ} 45^{\prime}-4^{\circ} 10^{\prime} \mathrm{S} ; 54^{\circ} 45^{\prime}-55^{\circ} 30^{\prime} \mathrm{W}\right)$, a SU-PA located in Pará State, Brazil (Figure 1). TNF covers 527,319 ha and is considered a prioritary conservation area internationally as it protects ecosystems and the cultural diversity of traditional peoples in a threatened part of the Amazon basin (ICMBio 2019). The climate of the region is humid tropical (Am in the Köppen classification) (Kottek et al. 2006). Total annual rainfall ranges from 974 to $3057 \mathrm{~mm}$ (mean $=1,906 \mathrm{~mm}$, data for 1985-2020 from the Belterra weather station; 2019 $=1,877 \mathrm{~mm}$, INMET 2021), and $70 \%$ is concentrated between December and June (Espírito-Santo et al. 2005). The vegetation is comprised mainly of dense tropical forest, and open tropical forest, chracterized by the presence of babassu palms (Attalea speciosa Mart.ex Spreng) (Espírito-Santo et al. 2005). Other economically important species, such as Brazil nut (Bertholletia excelsa H.B.K.), are present in both forest types (ICMBio 2019).

\section{Human occupation history}

We divided the TNF into a northern and a southern area, based on the human occupation history and the management plan devised by the Brazilian environmental authority (ICMBio 2019). There are 1,050 families living in the TNF, comprising 4,000 people in 23 traditional communities, mostly distributed along the margins of the Tapajós River (Figure 1). Residents are allowed to practice subsistence hunting, fishing, removal of non-timber forest products, and opening of small clearings for cultivation. Recently, two areas have been demarcated within the TNF to accommodate three indigenous villages of the Munduruku ethnic group. Most riverside and indigenous communities are located in the northern area, close to the cities of Santarém and Belterra, and a large settlement (São Jorge community) of 6,457 inhabitants in the immediate surroundings of the TNF between the northern and southern areas (Figure 1). The residents of São Jorge raise cattle using fire to form pastures, and use domestic dogs for poaching (Robert and Endo 2004). The northern area 

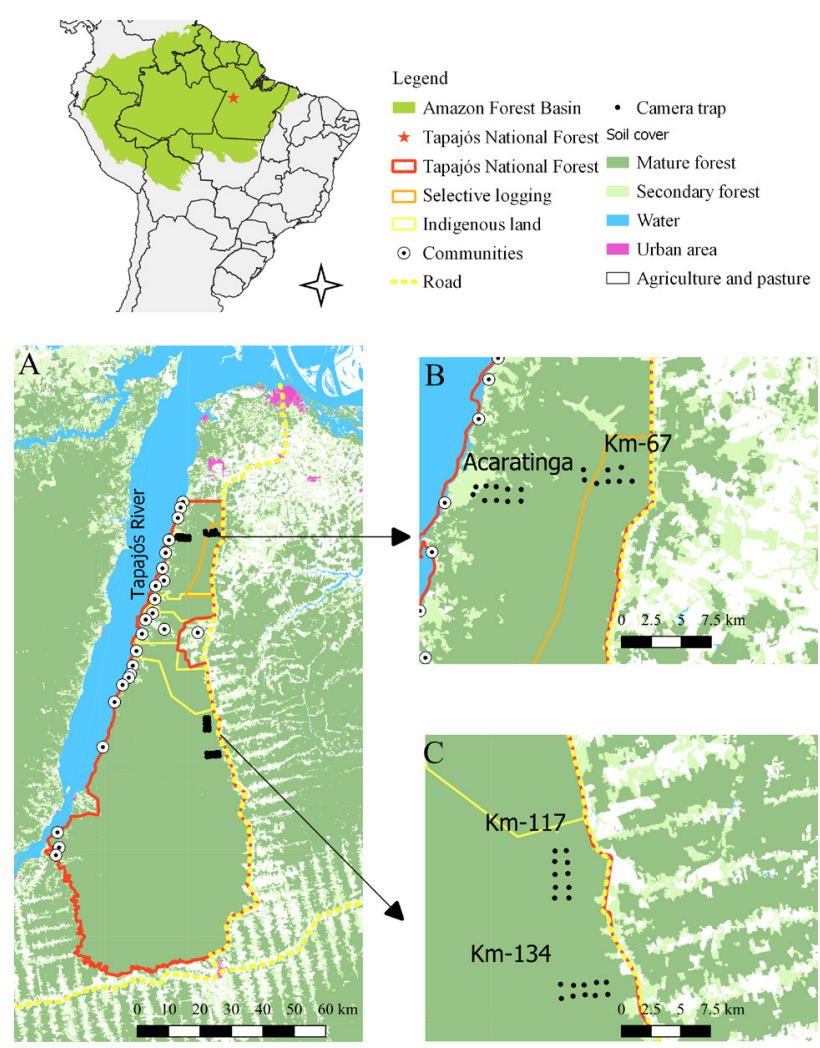

Figure 1. Location of the Tapajós National Forest (TNF) in the Amazon region, outline of the TNF showing the location of the traditional communities (A), and location of the sampling modules and camera-trap sites in the northern area (B) and in the southern area (C). This figure is in color in the online version.

also concentrates the most extensive area for reduced impact logging (RIL), with several roads that give access to the interior of the forest. In 2013 and 2014, approximately 2,000 ha of forest were logged in the RIL area in and around one of our sampling sites (Figure 1b). The northern area also underwent high forest degradation as a result of forest fires in 2015 and 2016 that burned approximately $20 \%$ of one sampling site during an extreme El Niño (França et al. 2020).

The southern area is more distant from the main population centers of Belterra and Santarém $(-300,000$ inhabitants), with only a few traditional communities on the Tapajós and Cupari river banks, as well as the larger village of Aveiro (Figure 1). Until 2017, most of this area was destined for permanent preservation and non-timber forest management (ICMBio 2019). However, the situation has recently changed, with the concession of a new area for logging, which began in 2017/2018 (ICMBio 2019).

\section{Data collection}

We sampled mammals over $1 \mathrm{~kg}$ mean body weight with camera traps in four standardized permanent RAPELD sampling modules (https://ppbio.inpa.gov.br/en/sites/ FLONA_Tapajos) of the PPBio research program (Magnusson et al. 2005; Rosa et al. 2021). Two modules are located in the northern area of the TNF ( $\mathrm{km} 67$ and Acaratinga, distant $5.6 \mathrm{~km}$ from each other) and two in the southern area $(\mathrm{km}$ 117 and $\mathrm{km} \mathrm{134}$, distant $7.3 \mathrm{~km}$ from each other, and 56 $\mathrm{km}$ from the northern modules) (Figure 1). Each module is a rectangle formed by two $5-\mathrm{km}$ trails joined at the ends by two $1-\mathrm{km}$ trails, and five regularly spaced $250-\mathrm{m}$ sampling plots separated by $1 \mathrm{~km}$ along each $5-\mathrm{km}$ trail (Magnusson et al. 2013). Next to each plot, we installed a single unbaited camera trap, totaling ten camera-trap stations per module (Figure 1b,c). Two camera traps used in the northern area did not work and were excluded from the analysis (Figure 1b, $\mathrm{km} \mathrm{67),} \mathrm{resulting} \mathrm{in} \mathrm{an} \mathrm{effective} \mathrm{sample} \mathrm{size} \mathrm{of} 20$ cameratrap stations in the southern, and 18 in the northern area. We used the following camera-trap models: Bushnell $12 \mathrm{Mp}$ Natureview Cam Essential HD Low Glow $(N=12)$, Primus Proof Cam 3 Review $^{\bullet}(N=5)$, and Moultrie A5 Low Glow Game Camera $^{\oplus}(N=3)$.

We sampled from June 2019 to January 2020, during the dry season. Stations were sampled sequentially because we did not have sufficient cameras to sample all stations simultaneously (Supplementary Material, Table S1). Cameras were positioned 30 to $40 \mathrm{~cm}$ above ground, programmed to work $24 \mathrm{~h}$ per day. Each camera operated for at least 34 days at each station. Effort per station ranged from 34 to 69 days, which is considered sufficient for the estimation of species detection and richness at one sampling point (Kays et al. 2020). Total effort was 1,868 camera-trap.days (northern area $=942$, southern area $=926)$. We identified the photographed species with a specialized field guide (Reis et al. 2010), following our expertise and consulting specialist researchers for some groups. The species taxonomy was based on the Official list of Brazilian Mammals from the Brazilian Society of Mammalogy (Abreu-Jr et al. 2021). The research was authorized by license SISBIO \# 67787-3 issued by Instituto Chico Mendes de Conservação da Biodiversidade.

\section{Data analysis}

We used a 30-minute interval as a criterion for defining independent captures of the same species at the same cameratrap station (Michalski et al. 2015; Alvarenga et al. 2018; Palmeirim et al. 2018). When more than one animal appeared in a single event, each was considered an individual record. We produced rarefaction curves and calculated expected species richness using the Chao estimator with package iNEXT (Hsieh et al. 2016), using camera-trap day as the sampling unit. We calculated the sampling sufficiency based on the percentage of observed species in relation to the total number of species estimated.

To compare the species composition between modules and areas (north and south), we standardized the minimum monitoring period as 34 days for all camera-trap stations to eliminate sampling bias. We carried out two non-metric multidimensional scaling analyses (NMDS) (Oksanen et 
al. 2019), one with presence and absence data using the Jaccard distance, and one with the number of records using the Bray-Curtis distance. The data were standardized with the "decostand" function (Oksanen et al. 2019). We used the analysis of similarity (ANOSIM) to compare species composition between modules and areas with the distances produced by association matrices (Oksanen et al. 2019).

We used a Kruskal-Wallis test to compare the number of recorded individuals for species with at least ten records (data standardized for 34 days) among modules, and a Wilcoxon test to compare the records between areas. We performed all analyses in the $\mathrm{R}$ software version 4.0.5 (R Core 2021).

We estimated the defaunation of each region as a measure of species loss and reduction of animal biomass, using a defaunation index proposed by Giacomini and Galetti (2013):

$$
D_{(r, f)}=\frac{\sum_{k-1}^{\mathrm{S}} \omega_{k}\left(\mathrm{~N}_{k, r}-\mathrm{N}_{k, f}\right)}{\sum_{k-1}^{\mathrm{S}} \omega_{k}\left(\mathrm{~N}_{k, r}+\mathrm{N}_{k, f}\right)}
$$

where:

$f=$ the focal mammal assemblage

$r=$ a reference mammal assemblage used to estimate defaunation in other sites

$S=$ the total number of species composing the mammal assemblage of all sites

$k=$ identification of species

$N_{k, f}=$ biomass, records or presence of species $\mathrm{k}$ in focal assemblage $f$

$N_{k, \mathrm{r}}=$ biomass, records or presence of species $\mathrm{k}$ in reference assemblage $r$

$\omega_{k}=$ importance of species $k$ to defaunation

$\mathrm{D}_{(r, f)}=$ defaunation of focal assemblage $f$ compared to reference assemblage $r$

The concept of defaunation demands the comparison between two assemblages, one focal (where defaunation is being evaluated) and one reference assemblage (representing a pristine or less defaunated site) (Giacomini and Galetti 2013). The criteria to define the reference assemblage depend on the research question, but also on the data available. Thus, the defaunation index represents the dissimilarity between two assemblages, ranging from 0 (no defaunation in the focal assemblage relative to the reference assemblage) to 1 (the focal assemblage is completely defaunated relative to the reference assemblage).

We calculated the defaunation of our study areas in two ways: for species presence (Species Defaunation Index - SDI) and for mammal biomass (Biomass Defaunation Index BDI). For estimating SDI we used as reference assemblage (r) the Amazonia National Park, which is considered one of best preserved sites in the Amazon and is close $(-150 \mathrm{~km})$ to our study site (Supplementary Material, Table S2; Oliveira et al. 2016). We used the mean body size of the species ( $\mathrm{kg}$ by $3 / 4$ power, as indicated by Giacomini and Galetti 2013) as importance value $(\omega)$, as ecology and life history of mammals can be inferred from body size (Giacomini and Galetti 2013). For the estimation of BDI, we used data from camera-trap surveys conducted in the continuous forest of the Balbina Hydroelectric Reservoir Reserve as reference assemblage ( $\mathrm{r}$ ) (Supplementary Material, Table S2; Palmeirim et al. 2018), because capture-rate data of species records in the Amazonia National Park were not available. The camera-trap design of Palmerin et al. (2018) was similar to ours (30 unbaited camera traps placed $30-40 \mathrm{~cm}$ above ground, 30 effort days per camera, and 30-min interval for independent captures).

Balbina Reserve is located in the central Amazon Basin, in a region with low forest loss and presents a higher number of records of large species, such as Tayassu pecari and Tapirus terrestris, than TNF, which account for most of the biomass of non-primate mammals in neotropical forests (Pontes 2004; Galetti et al. 2017). Biomass was chosen for $\mathrm{N}$ in the equation above following Giacomini and Galetti (2013), since biomass tends to be more robust to natural fluctuations due to compensatory effects in animal population dynamics (e.g., population increase of small species in response to decrease of large ones).

We calculated biomass of species for each site (reference and focal assemblages) using the capture rate (Srbek-Araujo and Chiarello 2005), multiplied by mean body mass, and by mean group size for gregarious species (Supplementary Material, Table S2) (Galetti et al. 2009). Because biomass was already accounted for in this analysis, we maintained the importance value $(\omega)$ for all species equal to 1 . We considered only terrestrial species recorded in camera trap studies, and excluded arboreal species (primates and sloths) or species strictly associated with aquatic habitats (Lontra longicaudis, Hydrochoerus hydrochaeris).

Finally, we compared the results of our study areas to the defaunation observed in six other Amazonian sites (only terra firme forest) (Supplementary Material, Figure S1), calculating SDI and BDI from presence/absence data and capture rates informed in the respective references (Supplementary Material, Table S2).

\section{RESULTS}

We recorded 13 mammal families and 22 species in the TNF (Table 1), 16 species in the northern area and 20 in the southern area. The Chao estimator showed that our sampling effort was sufficient to record $78 \%$ of species richness in the northern area and $88.9 \%$ in the southern area. The estimated values of species richness suggest no difference between the two areas (northern area: $20.5 \pm 7.1$, southern area: $22.5 \pm$ 2.9; Figure 2). 
Table 1. Species of medium and large-sized terrestrial mammals recorded through camera-trapping in the northern and southern areas of the Tapajós National Forest, in the western Brazilian Amazon ( $0=$ absence; $1=$ presence). The conservation status of each species globally (IUCN 2020b) and in Brazil (ICMBio/ MMA 2018) is shown. Taxonomy follows Abreu-Jr et al. (2021) (DD= deficient data, $\mathrm{LC}=$ Least concern, $\mathrm{NT}=$ Near threatened, $\mathrm{VU}=\mathrm{Vu}$ (nerable)

\begin{tabular}{llccccc}
\hline \multirow{2}{*}{ Order } & \multirow{2}{*}{ Species } & \multicolumn{2}{c}{ Area } & \multicolumn{2}{c}{ Status } \\
\cline { 3 - 6 } & & North & South & IUCN & Brazil \\
\hline Carnivora & Atelocynus microtis & 0 & 1 & NT & VU \\
Carnivora & Cerdocyon thous & 0 & 1 & LC & LC \\
\hline Carnivora & Leopardus pardalis & 1 & 1 & LC & LC \\
Carnivora & Leopardus wiedii & 1 & 1 & LC & VU \\
Carnivora & Panthera onca & 0 & 1 & NT & VU \\
\hline Carnivora & Puma concolor & 1 & 0 & LC & VU \\
Carnivora & Eirabarbara & 0 & 1 & LC & LC \\
Carnivora & Nasua nasua & 1 & 1 & LC & LC \\
\hline Cetoartiodactyla & Mazama americana & 1 & 1 & DD & LC \\
\hline Cetoartiodactyla & Mazama nemorivaga & 1 & 1 & LC & LC \\
\hline Cetoartiodactyla & Dicotyles tajacu & 1 & 1 & LC & LC \\
Cingulata & Dasypus beniensis & 1 & 1 & LC & LC \\
Cingulata & Dasypus novemcinctus & 1 & 1 & LC & LC \\
Cingulata & Cabassous unicinctus & 1 & 1 & LC & LC \\
\hline Cingulata & Euphractus sexcinctus & 1 & 0 & LC & LC \\
Cingulata & Priodontes maximus & 0 & 1 & LC & LC \\
\hline Didelphimorphia & Didelphis marsupialis & 1 & 1 & LC & LC \\
\hline Perissodactyla & Tapirus terrestris & 0 & 1 & VU & VU \\
\hline Pilosa & Myrmecophaga tridactyla & 1 & 1 & VU & VU \\
\hline Pilosa & Tamandua tetradactyla & 1 & 1 & LC & LC \\
\hline Rodentia & Cuniculus paca & 1 & 1 & LC & LC \\
\hline Rodentia & Dasyprocta croconota & 1 & 1 & DD & LC \\
\hline & & & & &
\end{tabular}

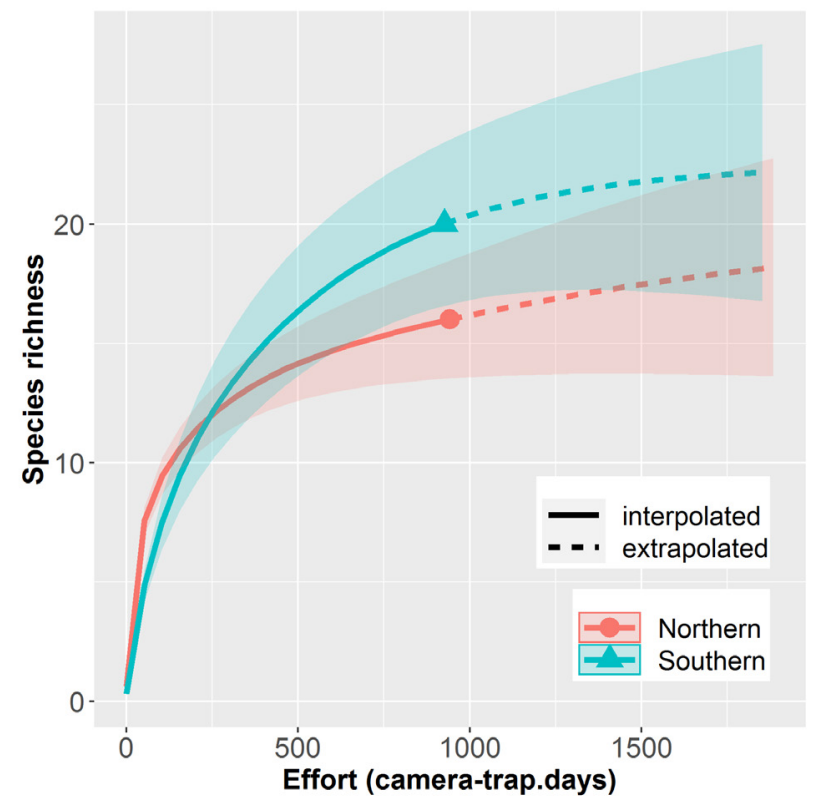

Figure 2. Rarefaction curves for medium and large-sized terrestrial mammal species sampled by camera-trapping in the northern and southern areas of the Tapajós National Forest (shaded areas represent the $95 \%$ confidence interval). This figure is in color in the online version.
Species composition differed significantly between the northern and southern areas for both presence-absence data (ANOSIM: $\mathrm{R}=0.11 ; \mathrm{p}=0.01$, stress $=0.19$ ) and number of records (ANOSIM: $\mathrm{R}=0.09, \mathrm{p}=0.01$, stress $=0.14$ ) (Figure $3)$. There were also significant differences among modules (Supplementary Material, Figure S2).

For some species, we obtained a significantly higher number of records in the northern than in the southern area: Dasyprocta croconota (W = 249.5, $\mathrm{P}=0.04)$, Cuniculus paca $(\mathrm{W}=291, \mathrm{P}=0.0007)$, Didelphis marsupialis $(\mathrm{W}=270, \mathrm{P}$ $=0.003$ ), and Dicotyles tajacu ( $\mathrm{W}=231, \mathrm{P}=0.03$ ) (Figure 4). There were also significant differences among modules (Supplementary Material, Figure S3).
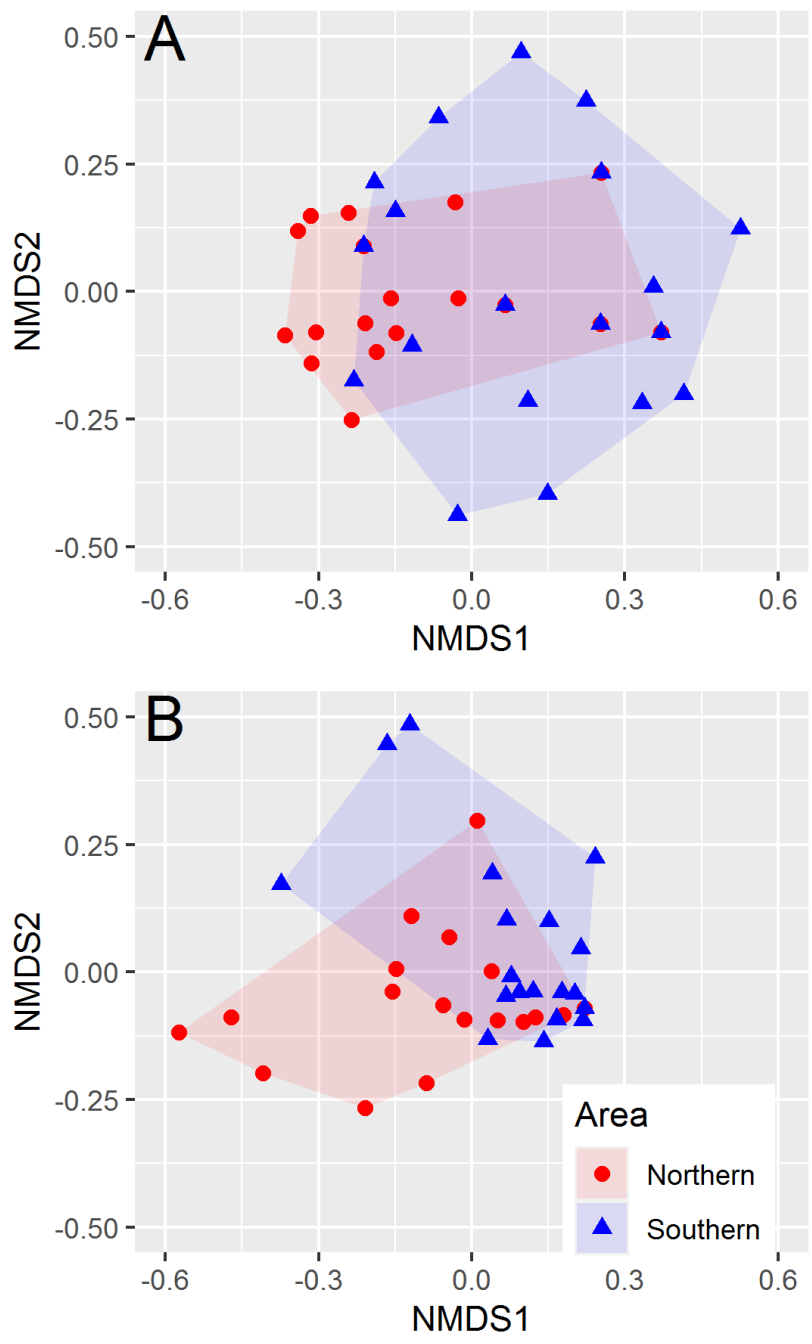

Figure 3. NMDS scores of species composition of medium and large-sized terrestrial mammals in camera-trap sampling sites in the northern and southern areas of the Tapajós National Forest, in the western Brazilian Amazon. Sampling effort was 34 days at each site. A -presence/absence data (stress $=0.19$ ); B independent record count data (stress $=0.14$ ). This figure is in color in the online version. 

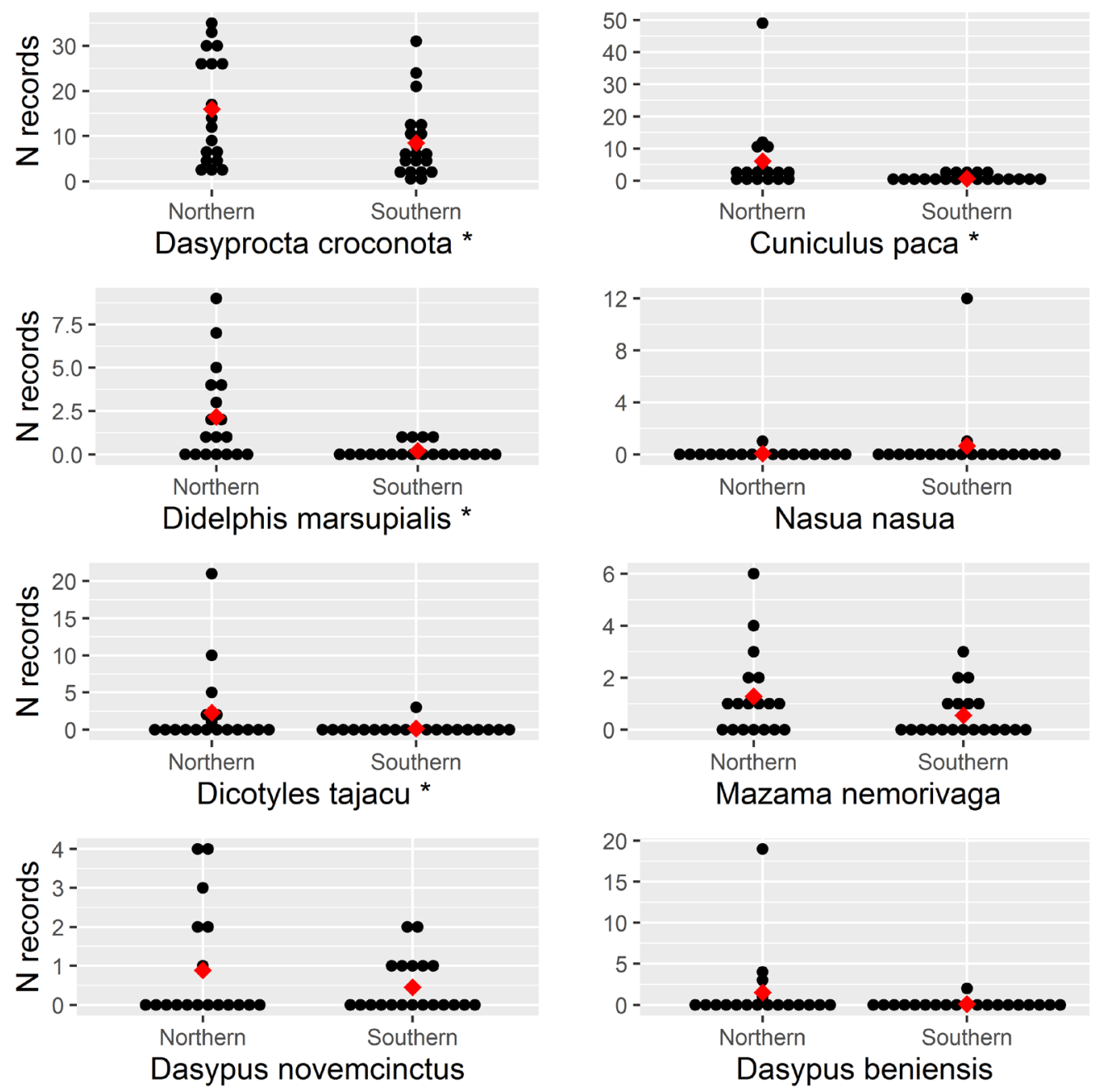

Figure 4. Number of independent camera-trap records for eight species of medium and large-sized terrestrial mammals at each sampling station in the northern and southern areas of the Tapajós National Forest, in the western Brazilian Amazon. Sampling effort was 34 days at each station. Red dots represent averages. * indicates a significant difference in number of records between areas. This figure is in color in the online version.

Species defaunation was lower in the southern (SDI $=0.08)$ than in the northern area $(\mathrm{SDI}=0.41)$. In other Amazonian reference sites, SDI ranged from 0.02 to 0.09 (Table 2). Conversely, BDI was higher in the southern (BDI $=0.90)$ than in the northern area $(\mathrm{BDI}=0.74)($ Table 2$)$. Biomass in the southern area $\left(380.8 \mathrm{~kg} 100 \mathrm{cam}_{\text {day }}{ }^{-1}\right)$ and in the northern area $\left(1,062.7 \mathrm{~kg} 100 \mathrm{cam}^{\text {dayy }}{ }^{-1}\right)$ corresponded, respectively, to $5.2 \%$ and $14.7 \%$ of the biomass in the reference assemblage (Balbina Reserve - continuous forest, biomass $=7,233.3 \mathrm{~kg} 100{\mathrm{cam} \cdot \text { day }^{-1}}^{-1}$ (Figure 5). Biomass defaunation for the other five Amazonian sites ranged from -0.0008 in Gurupi Biological Reserve (non-defaunated, the negative signal indicates that the biomass was higher than in the reference assemblage) to 0.45 in Amapá National Forest, with biomass corresponding to $100.1 \%$ and $41.7 \%$, respectively, relative to Balbina Reserve - continuous forest (Figure 5; Supplementary Material, Table S2).
Table 2. Defaunation in the Tapajós National Forest (northern and southern area) and in other Brazilian Amazonian protected areas relative to reference assemblages (RA): Amazonia National Park for the species defaunation index (SDI) and Balbina Reserve - continuous forest for the biomass defaunation index (BDI).

\begin{tabular}{llccc}
\hline Site ID & Site name & $\begin{array}{r}\text { Rainfall } \\
(\mathrm{mm}))^{\mathrm{a}}\end{array}$ & SDI & BDI \\
\hline 1a & Tapajós National Forest (northern area) & 1906 & 0.41 & 0.74 \\
\hline 1b & Tapajós National Forest (southern area) & 1906 & 0.08 & 0.90 \\
\hline 2 & Amapá National Forest & 2600 & 0.08 & 0.44 \\
\hline 3 & Amanã Sustainable Development Reserve & 2373 & 0.04 & 0.45 \\
\hline 4 & Geólogo Pedro de Moura Base Reserve & 2349 & 0.09 & 0.48 \\
\hline 5 & Gurupi Biological Reserve & 1800 & 0.02 & -0.0008 \\
$6 \mathrm{a}$ & Balbina Reserve - islands & 2376 & 0.03 & 0.44 \\
\hline $6 \mathrm{~b}$ & Balbina Reserve - continuous forest & 2376 & 0.03 & RA \\
\hline 7 & Amazonia National Park & 2028 & RA & DN \\
\hline
\end{tabular}

Data sources used to calculate defaunation: $1 \mathrm{a}, \mathrm{b}$ - this study; 2 - Michalski et al. (2015); 3 - Alvarenga et al. (2018); 4 - Santos and Mendes-Oliveira (2012); 5 Carvalho Jr et al. (2020); 6 - Palmeirim et al. (2018); 7 - Oliveira et al. (2016), DN = data not available. ${ }^{a}$ Data obtained from reference sources for each site. 


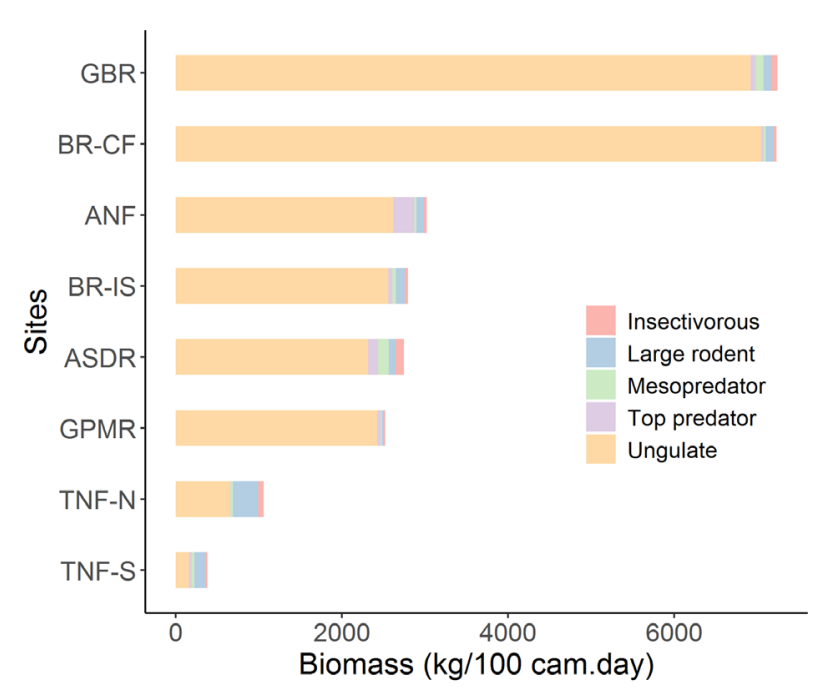

Figure 5. Estimated biomass (kg.100 cam.day $^{-1}$ ) of medium and large-sized terrestrial mammals in eight Brazilian Amazon protected areas. The species included in each functional group (insectivores, large rodents, mesopredators, top predators and ungulates) and the data sources are listed in Table S2, and the location of sites is shown in Figure S1, in the Supplementary Material. This figure is in color in the online version.

\section{DISCUSSION}

Our results suggest that the sampled areas in TNF maintain a high species richness of large and medium-sized terrestrial mammals, similarly to the other PAs used for comparison. The presence of endangered species, such as Priodontes maximus, Atelocinus microtis, Tapirus terrestris, among others, which were not recorded in a fragmented landscape nearby (Sampaio et al. 2010), reinforces the role of protected areas for mammal conservation in the Amazon and of the TNF in particular. Species composition, however, was not homogenous between the sampling areas in the TNF. The largest species were recorded in the southern area, while in the northern area mid-sized species predominated, which resulted in the southern area being more defaunated considering biomass and the northern area being more defaunated considering species presence. Thus, our hypothesis that the area with more intense human occupation should be more defaunated was only partially supported.

The presence of large-bodied mammal species in the southern part of the TNF can be attributed to the low land-use intensity and occupation in this area, while the higher poaching pressure in the northern area likely lead to a decrease in larger mammals, such as T. terrestris. In Santarém and Belterra, the probability of eating bush meat in rural or peri-urban areas is still very high (>70\%) (Torres et al. 2018), thus paved highway access to the protected areas within a 30 $\mathrm{km}$ radius north of the TNF potentially facilitate the entry of poachers and the elimination of large-bodied species. The absence of T. terrestris in the northern area of the TNF has been documented in a previous study (Sampaio et al. 2010), which may indicate their local extinction through poaching.

The logging activities in the northern area also may have contributed to change species composition. The cooperative managing selective logging activities in the TNF annually removes trees from at least 30 species (Coomflona 2015). The fruits of many of these species, such as the locally known as maçaranduba (Manilkara spp.), jatobá (Hymenaea spp.) and itaúba (Mezilaurus spp.) are consumed by fauna (Peres et al. 2003, O'farrill et al. 2013). Despite the use of reduced-impact logging, a decrease in the food availability for frugivores is still expected (Spaan et al. 2020).

Some medium-sized species, such as Cuniculus paca, Dasyprocta croconota, Didelphis spp., Dicotyles tajacu, and Mazama nemorivaga had higher capture rates, thus higher biomass in the northern area, resulting in a lower BDI. Some of these species are habitat generalists and can benefit from the absence of large competitors and predators (Galetti et al. 2015). Other factors in the northern area, such as fires and logging (in module $\mathrm{Km} 67$ ), favor the spread of secondary forests, which can benefit some species by increasing resources through the opening of clearings (Parry et al. 2007). Didelphis spp. and Dasyprocta spp., among other opportunistic species, can also increase in abundance in degraded environments (Michalski and Peres 2007; Jorge 2008). Thus, the high biomass of large rodents (D. croconota and C. paca) in the northern area may be an effect of forest degradation, which may increase the densities of Attalea palms (Araújo et al. 2012), a frequently used resource by large rodents (Cid et al. 2013). Although these species are seed dispersers, they are also seed predators, and may have negative impacts on seedling recruitment, impacting forest dynamics (Fadini et al. 2009; Brocardo et al. 2018).

The almost complete assemblages of large and medium ground-dwelling mammals (SDI $<0.10$ ) indicated by the low SDI in TNF and the other reported PAs may be related to the size and connectivity of Amazonian PAs. However, the high biomass defaunation in most sites $(\mathrm{BDI}>0.40$ ) relative to the reference assemblage also points to loss of abundance while the species assamblege is still nearly complete. Although we cannot attribute defaunation solely to anthropogenic causes, our results provide evidence that they play a key role.

The loss of largest mammal species is not random and follows classic defaunation patterns, according to which the largest species are the first and mostly affected (Dirzo et al. 2014). The absence of T. pecari and the low abundance of $T$. terrestris in our sampling were the main causes of high biomass defaunation in our study areas, as well as in other Amazonian sites in comparison to the reference assemblage (Balbina Reserve-continuous forest). Tayassu pecari tolerate low hunting pressure (Peres 2001; Antunes et al. 2016; Galetti et al. 2017) and reduces group size in proximity of human settlements 
(Reyna-Hurtado et al. 2016). There is evidence that the T. pecari population began to decline in the TNF after the construction of the BR-163 federal highway (Robert and Endo 2004), that connects central Brazil to Santarém (Pará state) and opened up the region to the settlement of many families close to the TNF and, consequently, increased poaching with guns and dogs. The advance of agriculture on the edges of the TNF may also have resulted in decline of T. pecari, which are often killed in other regions of Brazil in retaliation against the destruction and consumption of crops (Lima et al. 2019). We frequently heard of the extermination of entire herds of $T$. pecari during informal conversations with local residents, indicating its presence in TNF, which was confirmed by a recent sighting of a small herd (about 20 animals) in the southern area (September 2021, A.B. Castro, pers. obs.).

Large species such as T. pecari and T. terrestris have unique roles in structuring neotropical forests and a decline in their populations is a matter of concern (Altrichter et al. 2012; Cordeiro et al. 2016; Villar et al. 2020a), as it may lead to ecological extinction, i.e., the species is present, but in such low abundance that it does not contribute effectively to the ecological processes anymore (Valiente-Banuet et al. 2015). Tapirs are the largest herbivores and seed dispersers in the Neotropics, and are able to disperse large seeds over long distances, contributing to recruitment and gene flow of dispersed plant species (Bueno et al. 2013; Giombini et al. 2017). Tayassu pecari is considered an ecosystem engineer, impacting plant recruitment through seed predation and dispersal, herbivory and trampling of seedlings (Silman et al. 2003; Beck 2005; Keuroghlian and Eaton 2009). Thus, the local extinction or decline of these two species may compromise forest diversity and functioning in the long term (Villar et al. 2020a).

Several areas of the Amazon have been defaunated for decades (Redford 1992; Peres 2001; Peres and Palacios 2007, Antunes et al. 2016). We showed that, although species richness was little affected by anthropic impact within the TNF, biomass defaunation is occurring as a result of population decline or even local absence of certain species, which may be common throughout the Amazon (Peres and Palacios 2007; Antunes et al. 2016). The situation in TNF is worrying because, besides poaching, deforestation rates are accelerating in the region, pushed by the expansion of monoculture crops (Sauer 2018) and forest fires (França et al. 2020). At the same time, urban settlements near TNF are growing and getting closer to its borders, resulting in land expropriations and deforestation in municipalities that surround TNF ( $c a .75,000$ ha lost in the last 47 years (ICMBio 2019). Recently, the management plan of TNF was altered, excluding an ecological corridor that connected the northern and southern areas, increasing the concession areas for future logging operations to $25 \%$ of the total area of the TNF (ICMBio 2019). This alteration removes the more restrictive protection status from nearly all flat areas in the TNF and increases the vulnerability of still pristine areas, rendering them more vulnerable to hunters and illegal loggers, further compromising the funtional viability of mammal populations in the TNF.

It is urgent to stop the transformation of the habitat matrix around TNF and other PAs into anthropogenic environments for mammals. In PAs that remain relatively pristine, these threats should be anticipated through the creation of benign border environments that allow mammal transit and recolonization. At the same time, it is necessary to work with local stakeholders (farmers, indigenous people and traditional communities) to inform them about the importance of protecting mammalian fauna from long-term internal and external impacts. Mammals are not only important protein sources for traditional communities and indigenous peoples within SU-PAs, but also act as seed dispersers of several commercial tree species. Therefore, residents should be trained to quantify and sustainably manage their bush meat consumption (Luzar et al. 2011), while logging companies that manage forestry concessions and enviromental agencies may have to devise and implement protocols to prevent illegal logging, poaching and fire.

\section{CONCLUSIONS}

Our results showed that TNF still presents a rich assemblage of medium and large-sized mammals, although species composition differed between its northern and southern areas. Estimated biomass in both areas was lower than that observed in other Amazonian protection areas, implying that mammal abundance in TNF is impacted by human activities, such as poaching and forest degradation. This was the first assessment of mammal community through camera trapping in TNF, and it is important to highlight the spatial and temporal constraint of the study. We recommend a continuous monitoring of mammals community in TNF to better understand the dynamics of the effects of human activities on animal presence and abundance.

\section{ACKNOWLEDGMENTS}

We are very grateful to our field assistants and the residents of the Tapajós National Forest for their hospitality. We thank the Instituto Brasileiro de Conservação da Biodiversidade (ICMBio) [SISBIO no 67787-3] and the Cooperativa Mista da Floresta Nacional do Tapajós (Coomflona) for logistical support. This work was supported by Coordenação de Aperfeiçoamento de Pessoal de Nível Superior (CAPES), PROCAD-AM, [proc. \# 88881.314420/2019-01]; and PELD (LTER) POPA by the Conselho Nacional para o Desenvolvimento Científico e Tecnológico (CNPq) [proc. \# 441443/2016-8]. CRB received a post-doctoral fellowship from CAPES (Finance Code 001). DCPR received a master fellowship from CAPES. CR received a post-doctoral 
fellowship from CNPq. The English translation of the manuscript was supported by Edital 001/2020/PROPPIT/ UFOPA - Programa de Apoio à Publicação Científica em Periódicos - PAPCIP/UFOPA. We thank W. R. Spironello and T. de Oliveira for help with the identification of small Leopardus species. We are very grateful to William Magnusson for his comments on a previous version of the manuscipt. We also thank two anonymous reviewers for their comments.

\section{REFERENCES}

Abreu-Jr, E.F.; Casali, D.M.; Garbino, G.S.T.; Libardi, G.S.; Loretto, D.; Loss, A.C.; et al. 2021. Lista de Mamíferos do Brasil, versão 2021-1 (Abril). (https://www.sbmz.org/mamiferos-do-brasil/). Accessed on 25 May 2021.

Altrichter, M.; Taber, A.; Beck, H.; Reyna-Hurtado, R.; Lizarraga, L.; Keuroghlian, A.; et al. 2012. Range-wide declines of a key Neotropical ecosystem architect, the Near Threatened whitelipped peccary Tayassu pecari. Oryx, 46: 87-98.

Alvarenga, G.C.; Ramalho, E.E.; Baccaro, F.B.; da Rocha, D.G.; Ferreira-Ferreira, J.; Bobrowiec, P.E.D. 2018. Spatial patterns of medium and large size mammal assemblages in várzea and terra firme forests, Central Amazonia, Brazil. PLOS ONE, 13: $\mathrm{e} 0198120$.

Antunes, A.P.; Fewster, R.M.; Venticinque, E.M.; Peres, C.A.; Levi, T.; Rohe, F.; et al. 2016. Empty forest or empty rivers? A century of commercial hunting in Amazonia. Science Advances, 2: e1600936.

Araújo, G.C.; Junior, R.C. de O.; Oliveira, F. de A.; Gama, J.R. de V; Gonçalves, D.C.M.; Almeida, L.S. de. 2012. Comparação entre floresta primária e secundária com ocorrência de Attalea maripa (Aubl.) Mart.: estudo de caso na Amazônia Oriental. Floresta e Ambiente, 19: 325-335.

Beck, H. 2005. Seed predation and dispersal by peccaries throughout the neotropics and its consequences: a review and synthesis. In: Seed Fate: Predation, Dispersal and Seedling Establishment. CABI, Wallingford, p.77-115.

Beisiegel, B. de M. 2001. Notes on the coati, Nasua nasua (Carnivora: Procyonidae) in an Atlantic Forest area. Brazilian Journal of Biology, 61: 689-692.

Beisiegel, B. de M.; Ades, C. 2002. The behavior of the bush dog (Speothos venaticus Lund, 1842) in the field: a review. Revista de Etologia, 4: 17-23.

Bello, C.; Galetti, M.; Pizo, M.A.; Magnago, L.F.S.; Rocha, M.F.; Lima, R.A.F.; et al. 2015. Defaunation affects carbon storage in tropical forests. Science Advances, 1: e1501105.

Benítez-López, A.; Alkemade, R.; Schipper, A. 2017. The impact of hunting on tropical mammal and bird populations. Science, 356: 180-183.

Benítez-López, A.; Santini, L.; Schipper, A.M.; Busana, M.; Huijbregts, M.A.J. 2019. Intact but empty forests? Patterns of hunting-induced mammal defaunation in the tropics. PLoS Biology, 17: e3000247.

Brasil. 2000. Lei No 9.985, de 18 de julho de 2000. Institui o Sistema Nacional de Unidades de Conservação da Natureza. (http://www. planalto.gov.br/ccivil_03/leis/19985.htm).
Brocardo, C.R.; Pedrosa, F.; Galetti, M. 2018. Forest fragmentation and selective logging affect the seed survival and recruitment of a relictual conifer. Forest Ecology and Management, 408: 87-93.

Brocardo, C.R.; Zipparro, V.B.; de Lima, R.A.F.; Guevara, R.; Galetti, M. 2013. No changes in seedling recruitment when terrestrial mammals are excluded in a partially defaunated Atlantic rainforest. Biological Conservation, 163: 107-114.

Bruner, A.G. 2001. Effectiveness of Parks in Protecting Tropical Biodiversity. Science, 291: 125-128.

Bueno, R.S.; Guevara, R.; Ribeiro, M.C.; Culot, L.; Bufalo, F.S.; Galetti, M. 2013. Functional redundancy and complementarities of seed dispersal by the last neotropical megafrugivores. PLOS ONE, 8: e56252.

Carvalho Jr, E.A.R.; Mendonça, E.N.; Martins, A.; Haugaasen, T. 2020. Effects of illegal logging on Amazonian medium and large-sized terrestrial vertebrates. Forest Ecology and Management, 466: 118105 .

Chape, S.; Harrison, J.; Spalding, M.; Lysenko, I. 2005. Measuring the extent and effectiveness of protected areas as an indicator for meeting global biodiversity targets. Philosophical Transactions of the Royal Society B: Biological Sciences, 360: 443-455.

Cid, B.; Oliveira-Santos, L.G.R.; Mourão, G. 2013. Seasonal Habitat Use of Agoutis (Dasyprocta azarae) is Driven by the Palm Attalea phalerata in Brazilian Pantanal. Biotropica, 45: 380-385.

Cooke, R.S.C.; Eigenbrod, F.; Bates, A.E. 2019. Projected losses of global mammal and bird ecological strategies. Nature Communications, 10: 2279.

Coomflona. 2015. Plano Operacional Anual - POA Upa-1. Cooperativa Mista da FLONA do Tapajós - COOFLONA, Santarém, 93p.

Cordeiro, J.L.P.; Fragoso, J.M. V; Crawshaw, D.; Oliveira, L.F.B. 2016. Lowland tapir distribution and habitat loss in South America. PeerJ, 4: e2456.

Dirzo, R.; Young, H.S.; Galetti, M.; Ceballos, G.; Isaac, N.J.B.; Collen, B. 2014. Defaunation in the Anthropocene. Science, 345: 401-406.

Espírito-Santo, F.D.B.; Shimabukuro, Y.E.; Aragão, L.E.O. e C. de; Machado, E.L.M. 2005. Análise da composição florística e fitossociológica da floresta nacional do Tapajós com o apoio geográfico de imagens de satélites. Acta Amazonica, 35: 155-173.

Fadini, R.F.; Fleury, M.; Donatti, C.I.; Galetti, M. 2009. Effects of frugivore impoverishment and seed predators on the recruitment of a keystone palm. Acta Oecologica, 35: 188-196.

França, F.M.; Ferreira, J.; Vaz-de-Mello, F.Z.; Maia, L.F.; Berenguer, E.; Ferraz Palmeira, A.; et al. 2020. El Niño impacts on humanmodified tropical forests: Consequences for dung beetle diversity and associated ecological processes. Biotropica, 52: 252-262.

Galetti, M.; Bovendorp, R.S.; Guevara, R. 2015. Defaunation of large mammals leads to an increase in seed predation in the Atlantic forests. Global Ecology and Conservation, 3: 824-830.

Galetti, M.; Giacomini, H.C.; Bueno, R.S.; Bernardo, C.S.S.; Marques, R.M.; Bovendorp, R.S.; et al. 2009. Priority areas for the conservation of Atlantic forest large mammals. Biological Conservation, 142: 1229-1241. 
Galetti, M.; Brocardo, C.R.; Begotti, R.A.; Hortenci, L.; RochaMendes, F.; Bernardo, C.S.S.; et al. 2017. Defaunation and biomass collapse of mammals in the largest Atlantic forest remnant. Animal Conservation, 20: 270-281.

Geldmann, J.; Manica, A.; Burgess, N.D.; Coad, L.; Balmford, A. 2019. A global-level assessment of the effectiveness of protected areas at resisting anthropogenic pressures. Proceedings of the National Academy of Sciences, 116: 23209-23215.

Giacomini, H.C.; Galetti, M. 2013. An index for defaunation. Biological Conservation, 163: 33-41.

Giombini, M.I.; Bravo, S.P.; Sica, Y.V.; Tosto, D.S. 2017. Early genetic consequences of defaunation in a large-seeded vertebratedispersed palm (Syagrus romanzoffiana). Heredity, 118: 568-577.

Hsieh, T.C.; Ma, K.H.; Chao, A. 2016. iNEXT: an R package for rarefaction and extrapolation of species diversity (H ill numbers). Methods in Ecology and Evolution 7: 1451-1456.

ICMBio. 2019. Instituto Chico Mendes de Conservação da Biodiversidade. Plano de Manejo Floresta Nacional do Tapajós. Brasília, 316p. (https:/www.icmbio.gov.br/portal/images/ stories/plano-de-manejo/plano_de_manejo_flona_do_ tapajós_2019_vol1.pdf). Accessed on 01 Feb. 2021

INMET. 2021. Instituto Nacional de Meteorologia (INMET). (https:// bdmep.inmet.gov.br/\#). Accessed on 01 Feb. 2021.

Iwamura, T.; Lambin, E.F.; Silvius, K.M.; Luzar, J.B.; Fragoso, J.M. V. 2014. Agent-based modeling of hunting and subsistence agriculture on indigenous lands: Understanding interactions between social and ecological systems. Environmental Modelling \& Software, 58: 109-127.

Jorge, M.L.S.P. 2008. Effects of forest fragmentation on two sister genera of Amazonian rodents (Myoprocta acouchy and Dasyprocta leporina). Biological Conservation, 141: 617-623.

Kays, R.; Arbogast, B.S.; Baker-Whatton, M.; Beirne, C.; Boone, H.M.; Bowler, M.; et al. 2020. An empirical evaluation of camera trap study design: How many, how long and when? Methods in Ecology and Evolution, 11: 700-713.

Keuroghlian, A.; Eaton, D.P.; Longland, W.S. 2004. Area use by whitelipped and collared peccaries (Tayassu pecari and Tayassu tajacu) in a tropical forest fragment. Biological Conservation, 120: 411-425.

Keuroghlian, A.; Eaton, D.P. 2009. Removal of palm fruits and ecosystem engineering in palm stands by white-lipped peccaries (Tayassu pecari) and other frugivores in an isolated Atlantic Forest fragment. Biodiversity and Conservation, 18: 1733.

Kottek, M.; Grieser, J.; Beck, C.; Rudolf, B.; Rubel, F. 2006. World map of the Köppen-Geiger climate classification updated. Meteorologische Zeitschrift, 15: 259-263.

Lima, M.; Peres, C.A.; Abrahams, M.I.; da Silva Junior, C.A.; de Medeiros Costa, G.; dos Santos, R.C. 2019. The paradoxical situation of the white-lipped peccary (Tayassu pecari) in the state of Mato Grosso, Brazil. Perspectives in Ecology and Conservation, 17: 36-39.

Luzar, J.B.; Silvius, K.M.; Overman, H.; Giery, S.T.; Read, J.M.; Fragoso, J.M. V. 2011. Large-scale environmental monitoring by indigenous peoples. BioScience, 61: 771-781.

Magnusson, W.E.; Lima, A.P.; Luizão, R.; Luizão, F.; Costa, F.R.C.; Castilho, C.V. de; et al. 2005. RAPELD: a modification of the Gentry method for biodiversity surveys. Biota Neotropica, 5: 19-24.
Magnusson, W.E.; Braga-Neto, R.; Pezzini, F.; Baccaro, F.; Bergallo, H.; Penha, J.; et al. 2013. Biodiversidade e Monitoramento Ambiental Integrado: O Sistema RAPELD na Amazônia. Attema Editora, Santo André, 352p.

Michalski, F.; Peres, C.A. 2007. Disturbance mediated mammal persistence and abundance-area relationships in Amazonian forest fragments. Conservation Biology, 21: 1626-1640.

Michalski, L.J.; Norris, D.; de Oliveira, T.G.; Michalski, F. 2015. Ecological relationships of meso-scale distribution in 25 neotropical vertebrate species. PLOS ONE, 10: e0126114.

O’Farrill, G.; Galetti, M.; Campos-Arceiz, A. 2013. Frugivory and seed dispersal by tapirs: an insight on their ecological role. Integrative Zoology, 8: 4-17.

Oksanen, J.; Guillaume, B.F.; Michael, F.; Roeland, K.; Legendre, P.; Dan, M.; et al. 2019. Vegan: Community Ecology Package. ( https://cran.r-project.org/web/packages/vegan/vegan.pdf)

Oliveira, B.D.; Norris, D.; Michalski, F. 2018. Assessment of Attractants for Neotropical Mammals. Tropical Conservation Science, 11: 194008291880066.

Oliveira, T.G.; Mazim, F.D.; Vieira, O.Q.; Barnett, A.P.A.; Silva, G. do N.; Soares, J.B.G.; et al. 2016. Nonvolant Mammal Megadiversity and Conservation Issues in a Threatened Central Amazonian Hotspot in Brazil. Tropical Conservation Science, 9: 194008291667234.

Paglia, A.P.; Da Fonseca, G.A.; Rylands, A.B.; Herrmann, G.; Aguiar, L.M.; Chiarello, A.G.; et al. 2012. Lista Anotada dos Mamíferos do Brasil $2^{a}$ Edição/Annotated Checklist of Brazilian Mammals. Occasional Papers in Conservation Biology, 6: 1-82.

Palmeirim, A.F.; Benchimol, M.; Morante-Filho, J.C.; Vieira, M.V.; Peres, C.A. 2018. Ecological correlates of mammal $\beta$-diversity in Amazonian land-bridge islands: from small- to large-bodied species. Diversity and Distributions, 24: 1109-1120.

Parry, L.; Barlow, J.; Peres, C.A. 2007. Large-vertebrate assemblages of primary and secondary forests in the Brazilian Amazon. Journal of Tropical Ecology, 23: 653-662.

Peres, C.A. 2001. Synergistic effects of subsistence hunting and habitat fragmentation on Amazonian forest vertebrates. Conservation Biology 15: 1490-1505.

Peres, C.A.; Barlow, J.; Haugaasen, T. 2003. Vertebrate responses to surface wildfires in a central Amazonian forest. Oryx, 37: 97-109.

Peres, C.A.; Palacios, E. 2007. Basin-wide effects of game harvest on vertebrate population densities in Amazonian forests: implications for animal-mediated seed dispersal. Biotropica, 39: 304-315.

Pontes, A.R.M. 2004. Ecology of a community of mammals in a seasonailly dry forest in Roraima, Brazilian Amazon. Mammalian Biology, 69: 319-336.

R Core. 2021. R: A Language and Environment for Statistical Computing. R Foundation for Statistical Computing, Vienna, Austria. (https://www.r-project.org/).

Redford, K.H. 1992. The empty forest. BioScience, 42: 412-422.

Reis, N.R.; Peracchi, A.L.; Fregonezi, M.N.; Rossaneis, B.K. 2010. Mamiferos do Brasil: Guia de Identificação. 1st ed. Technical Books Editora, Rio de Janeiro, 560p. 
Reyna-Hurtado, R.; Beck, H.; Altrichter, M.; Chapman, C.A.; Bonnell, T.R.; Keuroghlian, A.; et al. 2016. What Ecological and Anthropogenic Factors Affect Group Size in White-lipped Peccaries (Tayassu pecari)? Biotropica, 48: 246-254.

Robert, A.N.A.P.; Endo, W. 2004. Diagnóstico e plano para o manejo da fauna da Floresta Nacional do Tapajós. IBAMA, Santarém, 104p.

Roopsind, A.; Caughlin, T.T.; Sambhu, H.; Fragoso, J.M. V; Putz, F.E. 2017. Logging and indigenous hunting impacts on persistence of large Neotropical animals. Biotropica, 49: $565-575$.

Rosa, C.; Baccaro, F.; Cronemberger, C.; Hipólito, J.; Barros, C.F.; Rodrigues, D.D.E.J.; et al. 2021. The Program for Biodiversity Research in Brazil: The role of regional networks for biodiversity knowledge, dissemination, and conservation. Anais da Academia Brasileira de Ciências, 93: e20201604.

Sampaio, R.; Lima, A.P.; Magnusson, W.E.; Peres, C.A. 2010. Long-term persistence of midsized to large-bodied mammals in Amazonian landscapes under varying contexts of forest cover. Biodiversity and Conservation, 19: 2421-2439.

Santos, F. da S.; Mendes-Oliveira, A.C. 2012. Diversidade de mamíferos de médio e grande porte da regiáo do rio Urucu, Amazonas, Brasil. Biota Neotropica, 12: 282-291.

Sauer, S. 2018. Soy expansion into the agricultural frontiers of the Brazilian Amazon: The agribusiness economy and its social and environmental conflicts. Land Use Policy, 79: 326-338.

Schipper, J.; Chanson, J.S.; Chiozza, F.; Cox, N.A.; Hoffmann, M.; Katariya, V.; et al. 2008. The status of the world's land and marine mammals: diversity, threat, and knowledge. Science, 322: $225-230$.

Silman, M.R.; Terborgh, J.W.; Kiltie, R.A. 2003. Population regulation of a dominant rain forest tree by a major seed predator. Ecology, 84: 431-438.

Sobral, M.; Silvius, K.M.; Overman, H.; Oliveira, L.F.B.; Raab, T.K.; Fragoso, J.M. V. 2017. Mammal diversity influences the carbon cycle through trophic interactions in the Amazon. Nature Ecology \& Evolution, 1: 1670.

Spaan, D.; Ramos-Fernández, G.; Bonilla-Moheno, M.; Schaffner, C.M.; Morales-Mávil, J.E.; Slater, K.; et al. 2020. Anthropogenic habitat disturbance and food availability affect the abundance of an endangered primate: a regional approach. Mammalian Biology, 100: 325-333.

Srbek-Araujo, A.C.; Chiarello, A.G. 2005. Is camera-trapping an efficient method for surveying mammals in Neotropical forests? A case study in south-eastern Brazil. Journal of Tropical Ecology, 21: $121-125$.

Stoner, K.E.; Riba-Hernández, P.; Vulinec, K.; Lambert, J.E. 2007. The role of mammals in creating and modifying seedshadows in tropical forests and some possible consequences of their elimination. Biotropica, 39: 316-327.

Torres, C.P.; Morsello, C.; Parry, L.; Barlow, J.; Ferreira, J.; Gardner, T.; et al. 2018. Landscape correlates of bushmeat consumption and hunting in a post-frontier Amazonian region. Environmental Conservation, 45: 315-323.

Valiente-Banuet, A.; Aizen, M.A.; Alcántara, J.M.; Arroyo, J.; Cocucci, A.; Galetti, M.; et al. 2015. Beyond species loss: the extinction of ecological interactions in a changing world. Functional Ecology, 29: 299-307.

Villar, N.; Siqueira, T.; Zipparro, V.; Farah, F.; Schmaedecke, G.; Hortenci, L.; et al. 2020a. The cryptic regulation of diversity by functionally complementary large tropical forest herbivores. Journal of Ecology, 108: 279-290.

Villar, N.; Paz, C.; Zipparro, V.; Nazareth, S.; Bulascoschi, L.; Bakker, E.S.; et al. 2020b. Frugivory underpins the nitrogen cycle. Functional Ecology, 35: 357-368.

\author{
RECEIVED: $17 / 05 / 2021$ \\ ACCEPTED: 25/09/2021 \\ ASSOCIATE EDITOR: Paulo D. Bobrowiec
}


SUPPLEMENTARY MATERIAL (only available in the electronic version)

Rosa et al. Species-rich but defaunated: the case of medium and large-bodied mammals in a sustainable use protected area in the Amazon

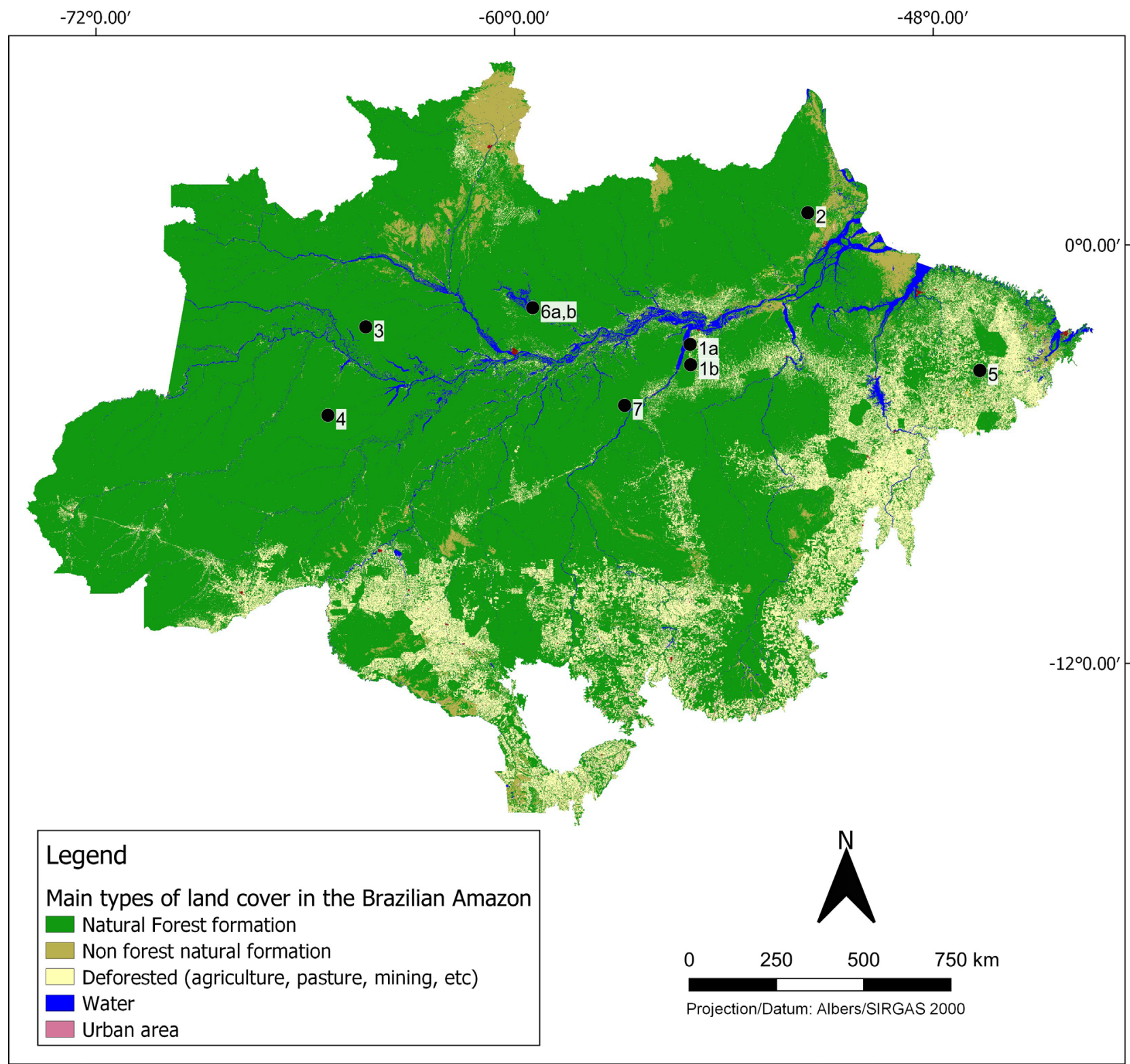

Figure S1. Location of survey sites of medium and large-sized terrestrial mammals referred in the study: Tapajós National Forest northern area (1a) and southern area (1b); Amapá National Forest (2); Amanã Sustainable Development Reserve (3); Geólogo Pedro de Moura Base Reserve (4); Gurupi Biological Reserve (5); Balbina Reserve - islands (6a) and continuous forest (6b); Amazonia National Park (7). 

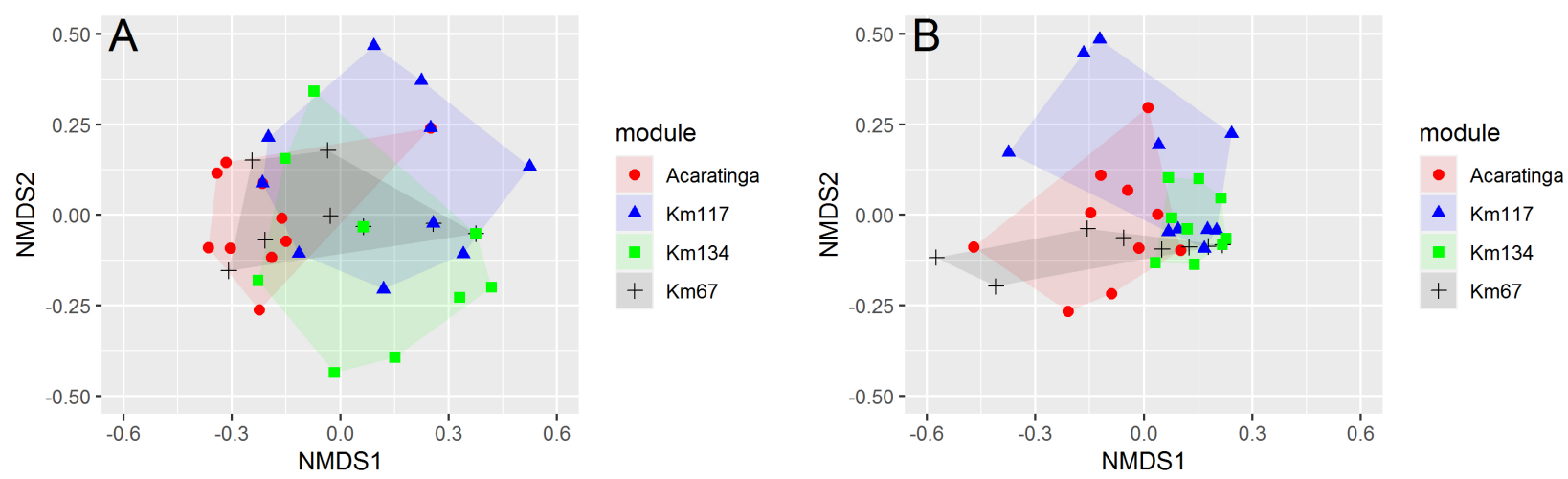

Figure S2. Differences in species composition of medium and large-sized terrestrial mammals among four RAPELD sampling modules (Acaratinga, Km 67, Km 117, and $\mathrm{Km}$ 134) in the Tapajós National Forest (western Brazilian Amazon). A - presence/absence data (ANOSIM: $R=0.09 ; p=0.03$, stress $=0.19$ ); $B$ - number of independent records (ANOSIM R: 0.08; $p=0.017$, stress $=0.14$ ).
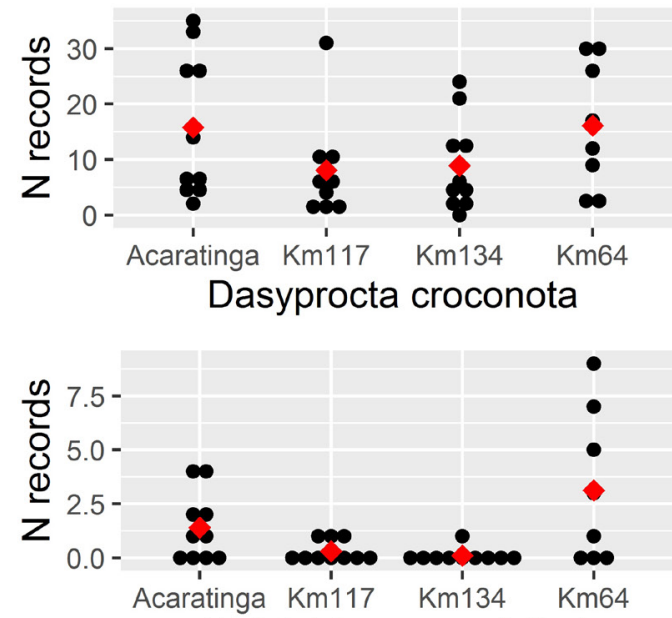

Didelphis marsupialis *
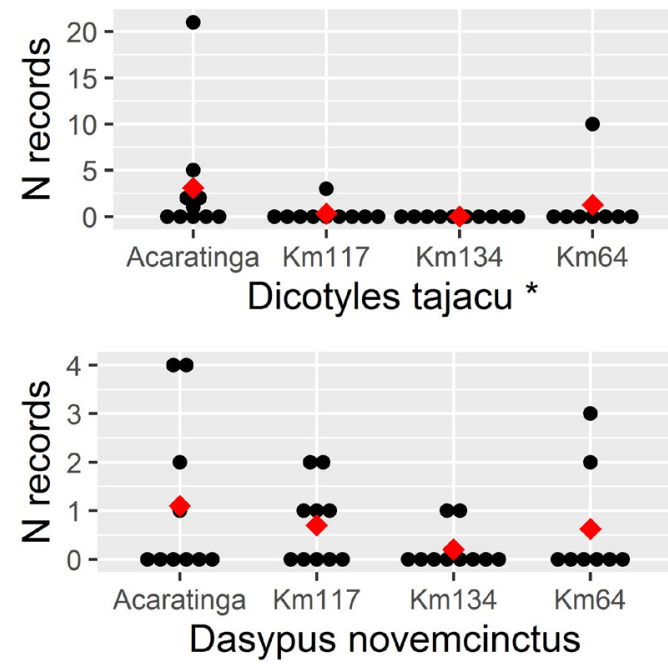
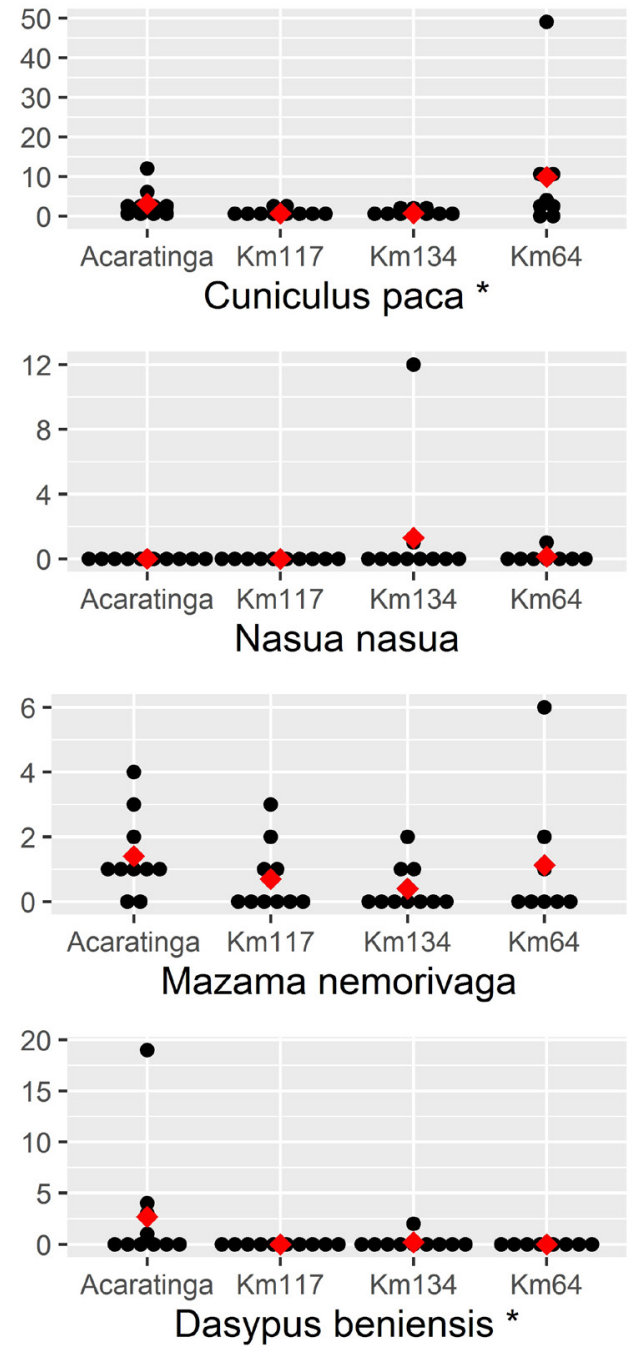

Figure S3. Number of independent camera-trap records for eight species of medium and large-sized terrestrial mammals for a standard sampling effort of 34 days for each of four RAPELD sampling modules (Acaratinga, Km 67, Km 117 and Km 134) in the Tapajós National Forest (western Brazilian Amazon). Red dots represent means. * indicates a significant difference in number of records among modules. 
Table S1. Sampling periods of camera trap surveys of large and medium-sized terrestrial mammals in four RAPELD sampling modules installed in the northern and southern part of the Tapajós National Forest (western Brazilian Amazon). See Material and Methods for details on the sampling design. (date_in = start date; date_end = final date of the sampling at this point).

\begin{tabular}{|c|c|c|c|c|c|}
\hline Area & Module & Camera model & ID_plot & date_in & date_end \\
\hline Northern & Acaratinga & Bushnell & ACARATNP0500 & 15 Nov 2019 & $22 \operatorname{Jan} 2020$ \\
\hline Northern & Acaratinga & Bushnell & ACARATNP1500 & 15 Nov 2019 & 22 Jan 2020 \\
\hline Northern & Acaratinga & Bushnell & ACARATNP2500 & 15 Nov 2019 & $22 \operatorname{Jan} 2020$ \\
\hline Northern & Acaratinga & Primus & ACARATNP3500 & 15 Nov 2019 & 22 Jan 2020 \\
\hline Northern & Acaratinga & Primus & ACARATNP4500 & 15 Nov 2019 & $22 \operatorname{Jan} 2020$ \\
\hline Northern & Acaratinga & Bushnell & ACARATSP0500 & 28 Aug 2019 & 10 Oct 2019 \\
\hline Northern & Acaratinga & Bushnell & ACARATSP1500 & 28 Aug 2019 & 10 Oct 2019 \\
\hline Northern & Acaratinga & Bushnell & ACARATSP 2500 & 28 Aug 2019 & 10 Oct 2019 \\
\hline Northern & Acaratinga & Bushnell & ACARATSP3500 & 28 Aug 2019 & 10 Oct 2019 \\
\hline Northern & Acaratinga & Bushnell & ACARATSP4500 & 28 Aug 2019 & 10 Oct 2019 \\
\hline Northern & $\mathrm{Km}-67$ & Bushnell & M67TLO1P1500 & 21 Nov 2019 & 21 Jan 2020 \\
\hline Northern & $\mathrm{Km}-67$ & Bushnell & M67TLO1P2500 & 21 Nov 2019 & 21 Jan 2020 \\
\hline Northern & $\mathrm{Km}-67$ & Bushnell & M67TLO1P4500 & 21 Nov 2019 & 21 Jan 2020 \\
\hline Northern & $\mathrm{Km}-67$ & Bushnell & M67TLO2P0500 & 27 Aug 2019 & 09 Oct 2019 \\
\hline Northern & $\mathrm{Km}-67$ & Bushnell & M67TLO2P1500 & 27 Aug 2019 & 09 Oct 2019 \\
\hline Northern & $\mathrm{Km}-67$ & Bushnell & M67TLO2P2500 & 27 Aug 2019 & 09 Oct 2019 \\
\hline Northern & $\mathrm{Km}-67$ & Bushnell & M67TLO2P3500 & 27 Aug 2019 & 09 Oct 2019 \\
\hline Northern & $\mathrm{Km}-67$ & Bushnell & M67TLO2P4500 & 27 Aug 2019 & 09 Oct 2019 \\
\hline Sounthern & $\mathrm{Km}-117$ & Primus & M117TNS1P0500 & $02 \mathrm{Jul} 2019$ & 12 Aug 2019 \\
\hline Sounthern & Km-117 & Bushnell & M117TNS1P1500 & 02 Jul 2019 & 12 Aug 2019 \\
\hline Sounthern & Km-117 & Bushnell & M117TNS1P2500 & $02 \mathrm{Jul} 2019$ & 12 Aug 2019 \\
\hline Sounthern & $\mathrm{Km}-117$ & Primus & M117TNS1P3500 & 02 Jul 2019 & 12 Aug 2019 \\
\hline Sounthern & Km-117 & Primus & M117TNS1P4500 & 02 Jul 2019 & 12 Aug 2019 \\
\hline Sounthern & Km-117 & Primus & M117TNS2P0500 & 13 Aug 2019 & 07 Sep 2019 \\
\hline Sounthern & Km-117 & Bushnell & M117TNS2P1500 & 13 Aug 2019 & 07 Sep 2019 \\
\hline Sounthern & $\mathrm{Km}-117$ & Primus & M117TNS2P2500 & 13 Aug 2019 & 07 Sep 2019 \\
\hline Sounthern & $\mathrm{Km}-117$ & Primus & M117TNS2P3500 & 13 Aug 2019 & 07 Sep 2019 \\
\hline Sounthern & Km-117 & Bushnell & M117TNS2P4500 & 13 Aug 2019 & 07 Sep 2019 \\
\hline Sounthern & Km-134 & Moultrie & M134TL01P0500 & 13 Aug 2019 & 15 Sep 2019 \\
\hline Sounthern & $\mathrm{Km}-134$ & Bushnell & M134TLO1P1500 & 13 Aug 2019 & 15 Sep 2019 \\
\hline Sounthern & $\mathrm{Km}-134$ & Moultrie & M134TLO1P2500 & 13 Aug 2019 & 15 Sep 2019 \\
\hline Sounthern & $\mathrm{Km}-134$ & Primus & M134TLO1P3500 & $06 \mathrm{Jul} 2019$ & 15 Aug 2019 \\
\hline Sounthern & $\mathrm{Km}-134$ & Primus & M134TL01P4500 & $06 \mathrm{Jul} 2019$ & 15 Aug 2019 \\
\hline Sounthern & $\mathrm{Km}-134$ & Bushnell & M134TLO2P0500 & 14 Oct 2019 & 28 Nov 2019 \\
\hline Sounthern & $\mathrm{Km}-134$ & Primus & M134TLO2P1500 & 16 Aug 2019 & 08 Oct 2019 \\
\hline Sounthern & Km-134 & Moultrie & M134TLO2P2500 & 16 Aug 2019 & 08 Oct 2019 \\
\hline Sounthern & $\mathrm{Km}-134$ & Bushnell & M134TLO2P3500 & 16 Aug 2019 & 08 Oct 2019 \\
\hline Sounthern & Km-134 & Bushnell & M134TLO2P4500 & 14 Oct 2019 & 28 Nov 2019 \\
\hline
\end{tabular}


Table S2. Data used to calculated the defaunation index: capture rate (number of independent captures per 100 cam.days) and record of mammals by camera trap sampling in Tapajós National Forest (1a- northern area; 1b- southern area) and in other Amazon sites (2- Amapá National Forest; 3- Amanã Sustainable Development Reserve; 4- Geólogo Pedro de Moura Base Reserve; 5- Gurupi Biological Reserve; 6a- Balbina Reserve - islands; 6b- Balbina Reserve - continuous forest; 7 - Amazonia National Park).

\begin{tabular}{|c|c|c|c|c|c|c|c|c|c|c|c|c|}
\hline Functional group & Species & Body mass $(\mathbf{k g})^{\mathrm{a}}$ & $\begin{array}{l}\text { Group } \\
\text { size }^{\mathrm{b}}\end{array}$ & $1 \mathrm{a}$ & $1 b$ & 2 & 3 & 4 & 5 & $6 a$ & $6 b$ & 7 \\
\hline Insectivorous & Cabassous unicinctus & 3.2 & 1 & 0.11 & 0.11 & 0.00 & 0.00 & 0.00 & 0.03 & 0.00 & 0.00 & NR \\
\hline Insectivorous & Dasypus kappleric & 9.5 & 1 & 4.16 & 0.43 & 0.90 & 0.00 & 0.00 & 0.00 & 0.31 & 0.22 & R \\
\hline Insectivorous & Dasypus novemcinctus & 3.65 & 1 & 2.56 & 1.08 & 0.20 & 6.70 & 0.00 & 0.00 & 6.27 & 4.00 & $\mathrm{R}$ \\
\hline Insectivorous & Dasypus sp & 6.575 & 1 & 0.21 & 0.43 & 0.00 & 0.00 & 0.10 & 4.79 & 0.00 & 0.00 & $\mathrm{R}$ \\
\hline Insectivorous & Euphractus sexcinctus & 5.4 & 1 & 0.11 & 0.00 & 0.00 & 0.00 & 0.00 & 0.00 & 0.00 & 0.00 & NR \\
\hline Insectivorous & Myrmecophaga tridactyla & 30.5 & 1 & 0.43 & 0.11 & 0.80 & 1.69 & 0.50 & 1.30 & 0.47 & 0.56 & $\mathrm{R}$ \\
\hline Insectivorous & Priodontes maximus & 26.8 & 1 & 0.00 & 0.32 & 0.00 & 1.11 & 0.00 & 0.16 & 0.08 & 0.22 & $\mathrm{R}$ \\
\hline Insectivorous & Tamandua tetradactyla & 5.2 & 1 & 0.75 & 0.11 & 0.20 & 0.19 & 0.00 & 0.56 & 0.08 & 0.06 & $\mathrm{R}$ \\
\hline Large Rodent & Cuniculus paca & 9.3 & 1 & 15.26 & 1.72 & 2.00 & 2.75 & 1.00 & 1.48 & 2.85 & 2.22 & $\mathrm{R}$ \\
\hline Large Rodent & Dasyprocta spp & 3.8 & 1 & 42.69 & 29.53 & 15.70 & 12.43 & 2.90 & 19.75 & 6.93 & 7.44 & $\mathrm{R}$ \\
\hline Large Rodent & Myoprocta spp & 1.1 & 1 & 0.00 & 0.00 & 8.60 & 6.65 & 0.00 & 0.00 & 47.30 & 34.50 & NR \\
\hline Mesopredator & Atelocynus microtis & 7.75 & 1 & 0.00 & 0.11 & 0.00 & 0.00 & 0.10 & 0.00 & 0.00 & 0.00 & $\mathrm{R}$ \\
\hline Mesopredator & Cerdocyon thous & 6.5 & 1 & 0.00 & 0.11 & 0.00 & 0.00 & 0.00 & 0.26 & 0.00 & 0.00 & NR \\
\hline Mesopredator & Didelphis marsupialis & 1.35 & 1 & 5.87 & 1.08 & 0.30 & 62.46 & 0.40 & 0.24 & 0.77 & 2.56 & $\mathrm{R}$ \\
\hline Mesopredator & Eira barbara & 7.0 & 1 & 0.00 & 0.22 & 0.80 & 0.96 & 0.10 & 0.63 & 0.30 & 0.39 & $\mathrm{R}$ \\
\hline Mesopredator & Galictis vitatta & 2.55 & 1 & 0.00 & 0.00 & 0.00 & 0.00 & 0.00 & 0.08 & 0.00 & 0.00 & NR \\
\hline Mesopredator & Herpailurus yagouaroundi & 4.5 & 1 & 0.00 & 0.00 & 0.00 & 0.00 & 0.00 & 0.00 & 0.05 & 0.06 & $\mathrm{R}$ \\
\hline Mesopredator & Leopardus pardalis & 9.5 & 1 & 0.43 & 0.65 & 1.00 & 3.13 & 0.70 & 0.74 & 1.87 & 1.06 & $\mathrm{R}$ \\
\hline Mesopredator & Leopardus sp & 4.125 & 1 & 0.00 & 0.00 & 0.00 & 0.00 & 0.00 & 0.29 & 0.00 & 0.00 & $\mathrm{R}$ \\
\hline Mesopredator & Leopardus wiedii & 6.0 & 1 & 0.11 & 0.22 & 0.20 & 0.19 & 0.00 & 0.11 & 0.11 & 0.39 & $\mathrm{R}$ \\
\hline Mesopredator & Nasua nasua & 5.1 & 7.4 & 2.37 & 3.99 & 1.48 & 0.71 & 0.00 & 15.65 & 3.96 & 2.06 & $\mathrm{R}$ \\
\hline Mesopredator & Procyon cancrivorus & 5.4 & 1 & 0.00 & 0.00 & 0.20 & 0.00 & 0.10 & 0.00 & 0.00 & 0.00 & $\mathrm{R}$ \\
\hline Mesopredator & Speothos venaticus & 6.0 & 4.5 & 0.00 & 0.00 & 0.10 & 0.14 & 0.00 & 0.05 & 0.00 & 0.00 & $\mathrm{R}$ \\
\hline Top predator & Panthera onca & 109.5 & 1 & 0.00 & 0.32 & 1.60 & 0.77 & 0.30 & 0.32 & 0.14 & 0.11 & $\mathrm{R}$ \\
\hline Top predator & Puma concolor & 46 & 1 & 0.21 & 0.00 & 1.70 & 0.67 & 0.40 & 0.56 & 0.74 & 0.33 & $\mathrm{R}$ \\
\hline Ungulate & Dicotyles tajacu & 26 & 9 & 20.17 & 1.94 & 77.40 & 44.24 & 2.70 & 19.51 & 71.04 & 30.00 & $\mathrm{R}$ \\
\hline Ungulate & Mazama americana & 36 & 1 & 0.64 & 0.54 & 4.10 & 2.55 & 1.40 & 0.90 & 1.82 & 4.00 & $\mathrm{R}$ \\
\hline Ungulate & Mazama nemorivaga & 20 & 1 & 4.38 & 1.62 & 6.10 & 0.92 & 0.00 & 0.69 & 1.02 & 1.89 & $\mathrm{R}$ \\
\hline Ungulate & Mazamasp & 28 & 1 & 0.75 & 0.11 & 0.00 & 0.00 & 0.00 & 7.09 & 0.00 & 0.00 & $\mathrm{R}$ \\
\hline Ungulate & Tapirus terrestris & 260 & 1 & 0.00 & 0.22 & 1.30 & 1.78 & 5.30 & 4.55 & 1.86 & 1.61 & $\mathrm{R}$ \\
\hline Ungulate & Tayassu pecari & 35 & 88.35 & 0.00 & 0.00 & 0.00 & 17.03 & 26.51 & 142.50 & 4.17 & 161.98 & $\mathrm{R}$ \\
\hline Total richness & & & & 16 & 20 & 20 & 20 & 15 & 22 & 21 & 21 & 23 \\
\hline
\end{tabular}

Data from: 1a,b - this study; 2 - Michalski et al. (2015); 3 - Alvarenga et al. (2018); 4 - Santos and Mendes-Oliveira (2012); 5 - Carvalho Jr et al. (2020); 6a,b - Palmeirim et al. (2018); 7 - Oliveira et al. (2016), $R=$ recorded by camera trap sampling, NR= not recorded by camera trap sampling.

a mean body mass was extracted from Paglia et al. (2012); ${ }^{\circ}$ sources for mean group size: Nasua nasua (Beisiegel 2001), Speothos venaticus (Beisiegel and Ades 2002),

Dicotyles tajacu (Keuroghlian et al. 2004), Tayassu pecari in Amazon forest (Reyna-Hurtado et al. 2016), ' includes D. kappleri, D. pastasae and D. beniensis formerly considered as a single species (Abreu et al. 2021). 